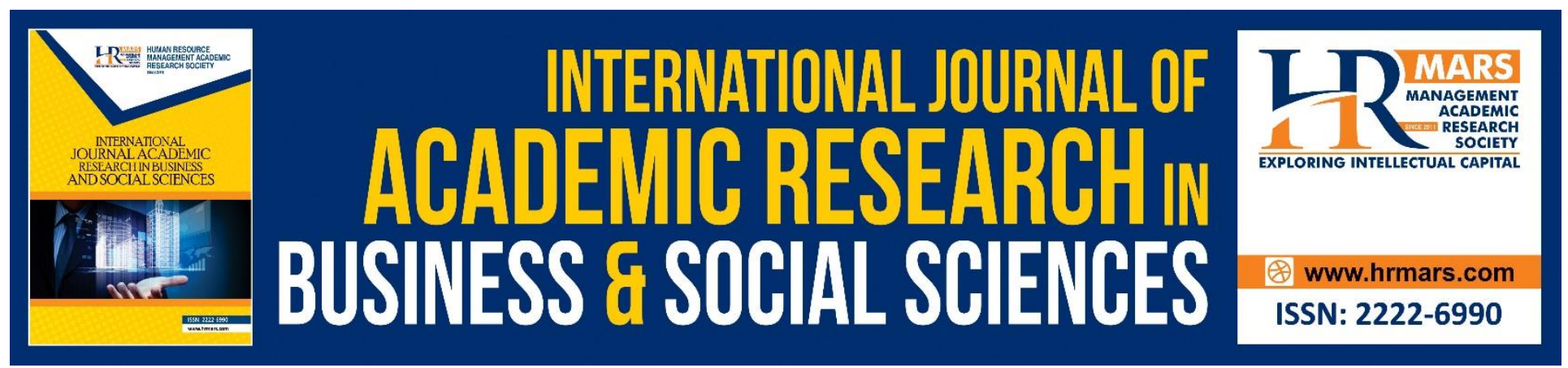

\title{
Resolution of Skin Contact Issue During Tawaf According to Shafi'iyyah Scholars and Hajj Advisory Committee of Tabung Haji
}

Jamalluddin Hashim, Wan Mohd Khairul Firdaus Wan Khairuldin, Rohaizan Baru, Syed Hadzrullathfi Syed Omar, Fauzi Yusoh, Dg. Hafizah Ag. Basir

To Link this Article: http://dx.doi.org/10.6007/IJARBSS/v9-i3/5688

DOI: $\quad 10.6007 /$ IJARBSS/v9-i3/5688

Received: 21 Feb 2019, Revised: 28 March 2019, Accepted: 06 April 2019

Published Online: 13 April 2019

In-Text Citation: (Hashim et al., 2019)

To Cite this Article: Hashim, J., Khairuldin, W. M. K. F. W., Baru, R., Omar, S. H. S., Yusoh, F., \& Basir, D. H. A. (2019). Resolution of Skin Contact Issue During Tawaf According to Shafi'iyyah Scholars and Hajj Advisory Committee of Tabung Haji. International Journal of Academic Research in Business and Social Sciences, 9(3), 362-372.

Copyright: (C) 2019 The Author(s)

Published by Human Resource Management Academic Research Society (www.hrmars.com)

This article is published under the Creative Commons Attribution (CC BY 4.0) license. Anyone may reproduce, distribute, translate and create derivative works of this article (for both commercial and non-commercial purposes), subject to full attribution to the original publication and authors. The full terms of this license may be seen at: http://creativecommons.org/licences/by/4.0/legalcode

Vol. 9, No. 3, 2019, Pg. 362 - 372

Full Terms \& Conditions of access and use can be found at http://hrmars.com/index.php/pages/detail/publication-ethics 


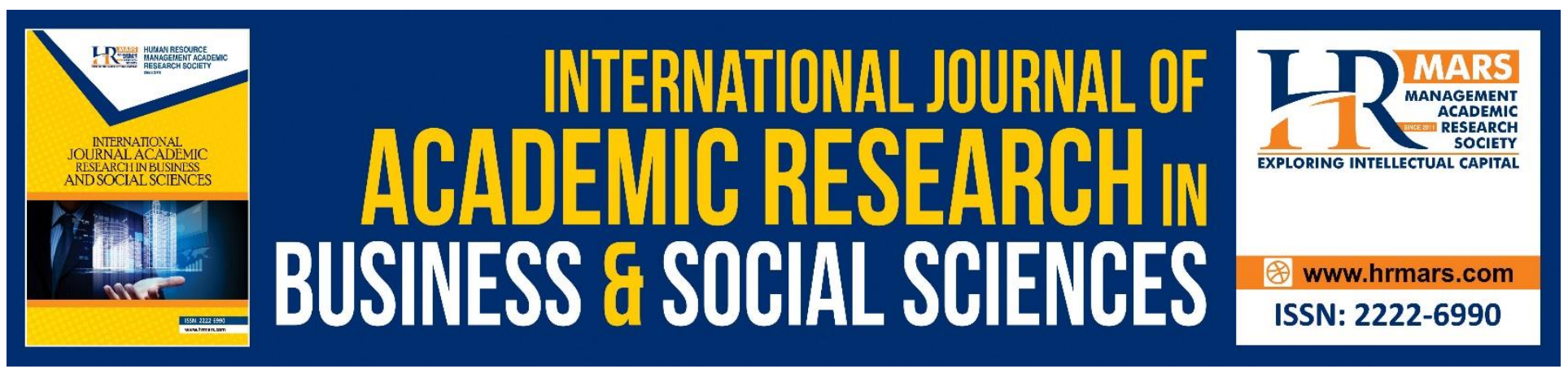

\title{
Resolution of Skin Contact Issue During Tawaf According to Shafi'iyyah Scholars and Hajj Advisory Committee of Tabung Haji
}

\author{
Jamalluddin Hashim, Wan Mohd Khairul Firdaus Wan Khairuldin, \\ Rohaizan Baru, Syed Hadzrullathfi Syed Omar, Fauzi Yusoh
} Fakulty Of Islamic Contemporary Studies, Universiti Sultan Zainal Abidin (UniSZA), Kampus Gong Badak, 21300 Kuala Nerus, Terengganu, Malaysia

Dg. Hafizah Ag. Basir

Faculty of Humanities (FKSW)

University Malaysia Sabah, Jalan UMS, 88400, Kota Kinabalu, Sabah, Malaysia

\begin{abstract}
According to the agreed opinion in Syafi'i sect, a touch without a cover between a marriageable adult man and a woman voids ablution of both, whether the touch happens intentionally or not, or whether with sexual desire or not. This absolutely will complicate the performance of tawaf among the pilgrims of Syafi'i sect without any occurrence of touch between marriageable adult men and women, as the tawaf place is always thronged with people either in hajj season or not. This paper aims to analyse various opinions posed by past and contemporary scholars of Syafi'i sect and by Tabung Haji personnel in solving the issue. To achieve the objective, a study through library method was done on the opinions of scholars from Syafi'i sect and reports from National Muzakarah of Hajj. Data were analysed through content analysis method to obtain the answer for the raised issue. Meanwhile, Tabung Haji has come with its own solution which has never been stated by Syafi'i scholars before. However, the solution for the issue is still in the scope of methods and principles of jurisprudence in Syafi'i sect.
\end{abstract}

Keywords: Void of Ablution, Tawaf, Syafi'i sect, Tabung Haji

Introduction

Hajj (pilgrimage) is the fifth pillars of Islam. Obligation, methods and wisdom of its execution are visualised clearly in several words of Allah Taala, among them is in Surah al-Baqarah (2:197) meaning:

(Time to perform) hajj is within several known months. Thus, one who set his intention to perform pilgrimage in the months, should not be in intimacy with wife and do mischieves, and should not quarrel in the time of hajj performance. And what you do 
INTERNATIONAL JOURNAL OF ACADEMIC RESEARCH IN BUSINESS AND SOCIAL SCIENCES

Vol. 9, No. 3, March, 2019, E-ISSN: 222 2-6990 ¿ 2019 HRMARS

from good deeds, thus Allah will know. Make preparation and truly the best preparation is takwa and be in takwa to Allah $O$ those who have intellects.

Hajj gathers several concepts of worship holistically. According to al-Sharbini (1994), individual who performs hajj is resembled as performing prayer, fasting, iktikaf, giving alms and struggling (jihad) in Allah's path.

Within all these, lies the specialty of hajj as it encompasses more than one form of worship which is integration of several forms of worship such as prayer, fasting, alms, iktikaf, sacrifice (korban) and others besides hajj itself has its own particular rituals. In many challenges and current situation, as a matter of fact, pilgrims could not avoid from facing situations which are raising various problems in worship matter during performance of hajj.

In managing the pilgrims from Malaysia, Hajj Advisory Committee of Tabung Haji is responsible of deciding fatwa related to their form of worship in the Holy Land. Current issues involving Malaysian pilgrims are presented and discussed in National Muzakarah of Hajj which is held after the end of hajj season in the current hijri year.

Among the issues which have been discussed in length and intensively in the history of National Muzakarah of Hajj is the issue of ablution void due to skin contact between marriageable individuals during tawaf. The issue has undergone several changes of fatwa by Hajj Advisory Committee of Tabung Haji. The aim is merely to solve the issue among Malaysian pilgrims following Shafi'i sect.

The issue of skin contact during tawaf is a big problem faced by Malaysian pilgrims which basically practise according to Shafi'l sect. This is because the ultimate opinion in Shafi'l sect is that, skin contact without cover between marriageable adult man and woman would void abadalah mlution of both, regardless whether the contact is accidental or intentional, and whether with sexual desire or not (al-Raniri 1937; al-Shafi'i 1993; al-Nawawi 1994; al-Nawawi 2000).

In deciding the fatwa of hajj, Hajj Advisory Committee of Tabung Haji holds to Shafi'l sect. Referring to Hafizah (2014), the binding of Shafi'i sect is due to the history regarding the spread of influence of Shafi'i sect in Malaysia which can be seen through the development of figh thought in the community. The effects and influences of Shafi'i sect in the community and administration in Malaysia are also seen in the approach of Hajj Advisory Committee of Tabung Haji through the reports of National Muzakarah of Hajj.

Due to the ultimate decision in Shafi'i sect that skin contact between marriageable individuals voids the ablution completely for both the toucher and the one being touched, it becomes a big problem to Malaysian pilgims of Shafi'i sect to abstain from skin contact during tawaf. This is in consequence of the situation where it is always crowded with people doing tawaf at any time and pushing that happens in the vicinity of tawaf area. 
Therefore, this article will discuss on the views of classical and contemporary Shafi'iyyah scholars and also of Hajj Advisory Committee of Tabung Haji in solving the issue of skin contact between marriageable people during tawaf. Then an analysis is done to the approaches brought forward by all these parties according to usuliyyah method in Shafi'i sect itself.

\section{METHODOLOGY}

The scope of this study is more towards focusing on the resolution of one problem in tawaf involving skin contact between marriageable people. This is a major issue in Shafi'i sect as the ultimate decision on Shafi'i sect in this problem that skin contact without cover between marriageable adult man and woman would void the ablution of both, whether it is done intentionally or not, whether it is with sexual desire or not. In fact, in the thronged condition in the tawaf area every year particularly in the hajj season, it is difficult to avoid from skin contact during tawaf.

This study applied the library method to the views of Shafi'iyyah scholars and reports from National Muzakarah of Hajj. Data were anaysed through content analysis method to obtain answer to the raised issue.

\section{DISCUSSION}

In Shafi'i sect, ultimate fiqh views are quoted from Ibn Hajar al-Haytami and al-Ramli's opinions. This is because of their second purification process (al-tanqih) after the first purification process performed by al-Imam al-Rafi'i and al-Imam al-Nawawi. The fiqh views after the second purification process were documented in their works especially in Tuhfah al-Muhtaj Bi Sharh al-Minhaj dan Nihayah al-Muhtaj Fi Sharh al-Minhaj. (al-Zuhayli 1992; al-Qawasimi 2003)

The first purification process done by al-Rafi' $i$ and al-Nawawi was achieved by scrutinising a large amount of grand figh works in the sect which had been written in the duration of four centuries after the decease of al-Shafi'i (m. 204H). Meanwhile, the second purification process done by Ibn Hajar al-Haytami and al-Ramli, basically stressed on the examination of works performed previously by al-Rafi'i dan al-Nawawi only. Sometimes, they proposed opinion contradicting with al-Rafi' $i$ and alNawawi in a certain problem, and then attempted to tarjih (validify) between the two opinions. At the same time, they also put forward their own contemplation of the problems which had not been touched before by al-Rafi'i and al-Nawawi in their works (al-Qawasimi, 2003).

Tuhfah al-Muhtaj Bi Sharh al-Minhaj written by Ibn Hajar al-Haytami achived the highest position among the muta'akhkhirin Shafi'iyyah scholars which is regarded as the main reference of figh among them besides Nihayah al-Muhtaj Ila Sharh al-Minhaj by al-Ramli. Nevertheless, if there is any contradiction between both of them, there are three inclination among Shafi'iyyah scholars:

1- Shafi'iyyah scholars in Hadramawt (Southern Yemen), Sham, Kurdistan, Daghistan and most of Yemen (Northern Yaman) and Hijaz are more prone to select Ibn Hajar al-Haytami's view particularly in Tuhfah al-Muhtaj Bi Sharh al-Minhaj.

2- Meanwhile, most of Shafi'iyyah scholars in Egypt are inclined towards al-Ramli's opinions especially in his book, Nihayah al-Muhtaj Ila Sharh al-Minhaj. 
3- For Shafi'iyyah scholars in Haramayn (Mekah and Madinah), in the beginning they preferred the views of Ibn Hajar al-Haytami. The condition started to differ when there was appearance of many Shafi'iyyah scholars from Egypt in the two Holy Lands. They had popularised the view of al-Ramli in their academic discussion circles until it spread throughout the two Holy Lands. Finally, Shafi'iyyah scholars in Haramayn who knew deeply both views of Ibn Hajar al-Haytami and al-Ramli, were keen to accept both opinions without validifying one of them (al-Saqqaf 1940; al-Kurdi 2009).

Besides them both, Zakariyya al-Ansari isone of the contributing figure of scholar to the spread of Shafi'i sect. This is because his views of figh especially in Fath al-Wahhab are one of the ultimate views in Shafi'i sect. However, according to many muta'akhhirin scholars of Shafi'i sect (those who lived between year $1004 \mathrm{H}$ until $1335 \mathrm{H}$ ), his views were considered rajih in the sect and final to be made fatwa if the matters were not touched in the works of Ibn Hajar al-Haytami and al-Ramli (alSaqqaf 1940; al-Kurdi 2009).

al-Khatib al-Sharbini is also a contributing figure of scholar in Shafi'i sect. His views are among of the final in Shafi'i sect. One of his famous fiqh books is Mughni al-Muhtaj Ila Ma'rifah Ma'ani Alfaz al-Minhaj. Despite, his views are regarded final to be made fatwa if they were not mentioned in figh works of Ibn Hajar al-Haytami, al-Ramli and Zakariyya al-Ansari (al-Saqqaf 1940; al-Qawasimi 2003; al-Kurdi 2009).

After the era of Ibn Hajar al-Haytami (m. 974H) and al-Ramli (m. 1004H), author scholars in Shafi'i sect are basically known as scholars who only cited figh problems decided by them both. In the development history of figh in Shafi'i sect, the author scholars are called as ashab al-hawashi. They are such as al-Ziyadi, Ibn Qasim, 'Amirah, al-Shabramalisi, al-Halabi, al-Shawbari and al-Anani. However, this did not prevent them from choosing other opinions to be mentioned in their works even though they clashed with the final opinion as decided by Ibn Hajar al-Haytami (m. 974H) and al-Ramli (m. 1004H) (al-Kaf 2008).

This phenomenon was obviously seen in the figh works written in this era of ashab al-hawashi. Scholars in the era of ashab al-hawashi were not in any position of mujtahid positions in Shafi'i sect. Indeed, they were in various levels of scholarship and depth of knowledge on nas-nas of fiqh in Shafi'i sect (al-Kaf 2008).

According to Ba Sudan (2018), it is permissible to make fatwa by any fiqh views posed by muta'akhhirin Shafi'iyah scholars such as Ibn Hajar al-Haytami, al-Ramli, al-Khatib al-Sharbini, Shaykh al-Islam Zakariyya al-Ansari, Ibn Ziyad, Abu Makhramah and ashab al-hawashi. Al-Kurdi (2009) stated that it is permissible to practise, make fatwa and perform judiciary action in the court with any views of them although some of the views contradict between each other. On the other hand, the views can be applied as long as they are not views produced as a result of carelessness (sahw), mistake (ghalat) or going astray from the basis of sect.

Based on this explanation, at the early stage of managing the pilgrims, the applied view in the issue of skin contact among marrieageable people during tawaf is of the final view in the sect in the 
ablution is voided in the toucher and the touched one whether the contact is intentional or not without cover by a marriageable person. This is the view stated by Shafi'iyyah scholars in their works such as Ibn al-Salah (2001), al-Nawawi (1994), Ibn Hajar al-Haytami (1996), al-Ramli (1993), al-Khatib al-Shirbini (1994), al-Raniri (1937), Dawud al-Fatani (t.th) and Muhammad al-Fatani (2005). The view is applied by authority of Tabung Haji since the era of sea vessel until 1988. The action of Hajj Advisory Committee of Tabung Haji in the usage of final view in this problem does conform with the basic concept of Shafi'i sect which is to make fatwa according to final view in the sect. However, the approach does not help a lot and unpractical in handling the problem in rituals among pilgrims in view of the crowding factor which is unevitable.

Therefore in year 1988, Hajj Advisory Committee of Tabung Haji suggested the pilgrims to apply the weak second opinion (muqabil al-asahh) in Shafi'i sect saying that ablution is voided in the toucher and not the one being touched by a marriageable person. The view has been proposed by Shafi'iyyah scholars such as Ibn al-Salah (2001), al-Nawawi (1994) adn al-Shatiri (1997). The objective for the choice by Tabung Haji authority was to ease the performance of tawaf ritual during crowding (Lukmanul Hakim 2011).

The preference of the weak opinion in the sect does not oppose the concept and basis in Shafi'i sect. Referring to al-Nawawi (t.th) and al-Kaf (2008), it is permissible for the mufti to make fatwa by a weak view in the sect when it involves public interest and need which is under consideration by the mufti himself without taking for granted the production of fatwa. Moreover, this is also the case when practising the final decision in the sect would lead to difficulty.

Meanwhile, Ibn Ziyad stated that it is alright to make fatwa by a view contradicting with the final view in the sect during the darurah. These words are to explain that applying the view opposing with the ultimate opinion of the sect during the decision in court or making fatwa during darurah is permissible and binding (Ba Sudan 2018).

Nevertheless, applying weak view of the sect in the issue still does not resolve the problem due to the crowded condition and pushing during tawaf forcing the pilgrims to touch marriageable woman and vice versa. This leads to the void of ablution (Mohd. Sirajuddin Siswadi Putera 2018). With that, Hajj Advisory Committee of Tabung Haji suggested that pilgrims follow Hambali sect to resolve the matter. This is due to the opinion in Hambali sect that ablution is not voided by touching woman except with accompaniment of sexual desire. Hajj Advisory Committee of Tabung Haji hoped that following Hambali sect in the issue of skin contact with mariageable person would be a solution to the problem (Syeikh Abdul Majid Mohd. Noor 1996). The resolution of this issue by holding to other sects has been mentioned by Shafi'iyyah scholars such as al-Haddar (t.th), al-Shatiri (1997), alKaf (2003), al-Shaqafah (2004), Ba Fadl (t.th) and Ibn Hafid (2013).

Holding to other sects is a concept approved by Shafi'i sect itself especially in the event of difficulty in applying the final view of the sect. Ibn Hajar al-Haytami (1996) said:

$$
\text { و إذا زادت المشقة في التزام مذهبنا فلا عيب على المتخلص بتقليد مذهب آخر }
$$

Meaning: 
If difficultiy increases in holding to our sect, thus it is not a curse to people withdrawing (from the difficulty) holding to other sects.

However, one of the conditions to hold to other sects is the absence of talfiq. Talfiq means combining two opinions resulting in a view which is not approved by both followed opinions. For example, someone performs ablution and then touches a woman without sexual desire and the ablution is voided according to Maliki sect. But, during the ablution, he does not rub the ablution body parts according to Shafi'i sect while the rubbing is the validifying condition of ablution according to Maliki sect. And then he performs prayer. In the condition, the prayer is voided based on the agreement between the two sects as both sects consider the void of his ablution as it does not comply to the condition of ablution and void of alution in respective sects (Ibn al-Jamal 1434H).

During the hajj courses organised by Tabung Haji, the pilgrims are given exposure and explanation regarding the guidelines of ablution, matters voiding the ablution and the conditions of tawaf according to Hambali sect. This is to prevent talfiq. They are explained on the advantages and difficulties which can be overcome through the alternative.

In spite of that, the matter is not easy to be applied in consequence of the fact that taklid problem is quite remote among the public. Moreover, Malaysia pilgrims who use to perform ablution according to Shafi'i sect guidelines have mistaken in the ablution as they do not comply with the ablution conditions in Hambali sect. For example, they forgot to wipe the whole head as in the ablution condition of Hambali sect as they get use to wipe only a small part of the head before. This causes their ablution to be not approved by Hambali sect. The effect is that their tawaf is invalid when there is skin contact during tawaf. This causes the religious teachers of Tabung Haji to be anxious and worried of the hajj status of the pilgrims. This becomes a hot issue discussed in the series of National Muzakarah of Hajj (Mohd. Sirajuddin Siswadi Putera 2018).

Finally in year 2006, Hajj Advisory Committee of Tabung Haji suggested that Malaysian pilgrims hold to a very weak view (shadh) in Shafi'i sect saying that it is not a void of ablution when there is skin contact between marriageable individuals in the conditothat the contact is not accompanied by sexual desire. This is the view of Ibn Surayj, a Shafi'iyyah scholar figure (m. 306H) (al-Nawawi, n.d.). This view has a similarity with the final view in Hambali sect, however it is a way out of talfiq dilemma which has become a complication for the Malaysian pilgrims that they should not plunge into it.

According to Balfaqih, it is more preferred to taklid to a weak wajah or qawl in the sect from taklid to a different sect. It is a difficulty for someone to follow other sect as he is not well-versed with the followed sect (Ba Fadl, n.d.).

Al-Kurdi (2009) also mentioned that taklid to a qawl or wajah in one's own sect with condition is preferred than taklid to other sects as iti is difficult to combine the rituals in taklid. 
At this time, the resolution of skin contact issue between marriageable people during tawaf becomes easier. This is by virtue of the fact that pilgrims do not need to perform ablution according to Hambali sect as suggested previously. Indeed, itt is adequate to follow Shafi'i sect guidelines which have become their routines. Then, they do tawaf based on the conditions in Shafi'i sect and refrain themselves from matters nullifying the ablution according to Shafi'i sect.

Actually, this final solution of Hajj Advisory Committee of Tabung Haji resembles one of the suggestions by Ba Fadl (n.d.). However, there is a little difference between the choice of opinion in Shafi'i sect between the two parties. Hajj Advisory Committee of Tabung Haji considered that the view of no void of ablution between the marriageable people in absence of sexual desire, applies to both the toucher and the touched one. Meanwhile, Ba Fadl differentiated between the two in which the toucher is not voided from ablution by touching woman without sexual desire. On the other hand, the touched one must hold to the second view of Shafi'i sect stating that no void of ablution for the touched person.

From other aspects, how is the status of Malaysian pilgrims from the aspect of practising fiqh views? Can Malaysian pilgrims be categorised as public who bind with any sect or not? According to al-Shatiri (2009), public are those who could not comprehend sharia laws from the evidences (dalil) and do not know the method of extracting laws (istinbat hukum) from the evidences. al-'Abbadi (1996) decided that public are those who are other than mujtahid.

Referring to al-Kaf (2008), the reality in majority of public nowadays is that they could not differentiate the views in every sects at all. This is due to the situation that every mufti today mention the views of all sects in each of their writings and fatwa. Fiqh studies in university do not bind to any sect owing to the spread of comparative fiqh studies.

According to Balfaqih, following the practice and words of scholars that if the public practise an action with the belief that it is a sharia law and it complies with renowned sect even though he does not know which view he is following, the action is valid as long as he does not believe in a view with a firm view (taklid sahih). Al-Jalal al-Suyuti quoted from a majority of scholars that thy made fatwa according to the four sects for the public especially for the public who do not bind to any sect and they do not know the methods and evidences of sects. When the practice complies with the view of a scholar, it would not be a problem to the practice (Ba'Alawi 1994; IbnHafid 2013).

\section{CONCLUSION}

Based on the history of fiqh view usage on the issue of skin contact during tawaf, it was found that Hajj Advisory Committee of Tabung Haji applied various views in Shafi'i sect to solve the issue. Beginning with the final view which is al-asahh, second to final view (muqabil al-asahh), following Hambali sect and finally applying one very weak view (shadh) in the sect.

All the application of the views own their basis in Shafi'l sect. This is on account of the fact that the final view in the sect which is al-asahh is the strongest basic view which should bre practised and made fatwa in Shafi'l sect. Meanwhile, view of muqabil al-asahh could be made fatwa if there is 
any need or darurah. Besides that, taklid to other sect is allowed if the fiqh views in Shafi'i sect is hard to be practised. Moreover, applying the weakest view (shadh) is permitted if it is difficult to follow other sects causing the conditions of taklid to be not fulfilled especially among public.

The final opinion of Hajj Advisory Committee of Tabung Haji in the issue is the most comprehensive and concrete solution. This is the easiest and most practical solution for Malaysian pilgrims during tawaf as in locally they hold to the final view of Shafi'i sect in the issue of void of ablution by skin contact between marriageable people. After that, there was no complaint anymore on the issue of skin contact between marriageable people during tawaf either from pilgrims of religious teacher in the Holy Land. This is a measure of wisdom which has been taken by Hajj Advisory Committee of Tabung Haji to resolve the issue in the scope of methods and basis in Shafi'i sect itself after a few times of applying different fiqh views in the sect previously. Although it only started in year 2006, the opinion has been applied long sinced Tabung Haji operated, however the attitude of carefulness by the committee in deciding a fatwa is highly appreciated.

From other aspects, principle scholars of Shafi'i scholars also approved and were keen to ease rituals by public when they validified that as long as the ritual of public comply with any view in the reputed sects, then the ritual is valid. This is a leniency of sharia to validify rituals of public who do not bind to any sect.

This is the openness of Shafi'iyyah scholars involving the rituals of public, which is applicable and appreciated nowadays when the ignorance is widespread, and systematic and comprehensive fiqh studies of sect is not followed by most of the public. When there is any confusion, they just ask their trusted teachers. Should Malaysian pilgrims categorised as public who do not bind to any sect to make easy the production of hajj fatwa, Hajj Advisory Committee of Tabung Haji is suggested to make fatwa by the most lenient and practical view and then validify the rituals of Malaysia pilgrims which is by selecting any fiqh view of muta'akhhirin Shafi'iyyah scholars such as Ibn Hajar al-Haytami, al-Ramli, al-Khatib al-Sharbini, Shaykh al-Islam Zakariyya al-Ansari, Ibn Ziyad, Abu Makhramah and ashab al-hawashi. With that, it is hoped that the concept of taysir and raf' al-haraj fought in the commencement of hajj rituals is also visualised in the scope of methods and principles in Shafi'i sect itself.

\section{ACKNOWLEDGEMENT}

This paper is founded on the research project of the Special Research Grant Inspire UniSZA/RMIC/2018/06. Special appreciation is owed to Ministry of Higher Education Malaysia (MOHE) and Universiti Sultan Zainal Abidin (UniSZA) for sponsoring and supporting this research.

\section{CORRESPONDING AUTHOR}

Dg. Hafizah Binti Ag. Basir, Lecturer, Faculty of Humanities (FKSW), University Malaysia Sabah, Jalan UMS, 88400, Kota Kinabalu, Sabah, Malaysia. Tel: +6088-320000 ext 5948.

Email: dhafizah@ums.edu.my 
INTERNATIONAL JOURNAL OF ACADEMIC RESEARCH IN BUSINESS AND SOCIAL SCIENCES

Vol. 9, No. 3, March, 2019, E-ISSN: 222 2-6990 @ 2019 HRMARS

\section{References}

Al-Fatani, D. (n.d.), Bughyah al-Tullab Li Murid Ma'rifah al-Ahkam Bi al-Sawab, Pulau Pinang: Percetakan Almuarif Sdn. Bhd.

Al-Fatani, M. (2005), al-Bahr al-Wafi Wa al-Nahr al-Safi, Kuala Lumpur: Khazanah Fathaniah

Al-Haddar, M. (n.d.), al-Hajj al-Mabrur Wa al-Sa'y al-Mashkur, Tarim: Dar al-Usul

Al-Kaf, H.A. (2003), al-Taqrirat al-Sadidah Fi al-Masa'il al-Mufidah, Tarim: Dar al-'Ilm Wa al-Da'wah

Al-Kaf, H.A. (2008), "al-Mu'tamad 'Ind al-Shafi'iyyah" (Disertasi MA, Fakulti Shari'ah, Universiti Islam Beirut)

Al-Sharbini, K. (1994), Mughni al-Muhtaj Ila Ma'rifah Ma'ani Alfaz al-Minhaj, Beirut : Dar al-Kutub al'Ilmiyyah

Al-Kurdi, M.S. (2009), al-Fawa'id al-Madaniyyah Fi Man Yufta Bi Qawlihi Min A'immah al-Shafi'iyyah, Kaherah : Dar al-Faruq Li al-Istithmar al-Thaqafiyyah

Al-Nawawi, Y.S. (1994), al-Idah Fi Manasik al-Hajj Wa al-'Umrah, Makkah: al-Maktabah al-Imdadiyyah Al-Nawawi, Y.S. (2000), Minhaj al-Talibin, Jil. 1. Beirut: Dar al-Basha ir al-Islamiyyah.

Al-Nawawi, Y.S. (n.d.), Kitab al-Majmu'Sharh al-Muhadhdhab, Jeddah : Maktabah al-Irshad

Al-Qawasimi, A.Y. (2003), al-Madkhal Ila Madhhab al-Imam al-Shafi'i, Jordan : Dar al-Nafa'is

Al-Ramli, S.D. (1993), Nihayah al-Muhtaj Ila Sharh al-Minhaj, Mekkah : Maktabah Dar al-Baz

Al-Raniri, S.N. (1937), al-Sirat al-Mustaqim Fi Fiqh Madhhab al-Imam al-Shafi'i radiy Allah 'anhu, Mesir : Sharikah Maktabah Wa Matba'ah Mustafa al-Babi al-Halabi Wa Awladihi

Al-Saqqaf, S. (1940), al-Fawa'id al-Makkiyyah Fi Ma Yahtajuhu Talabah al-Shafi'iyyah Min al-Masa'il Wa al-Dawabit Wa al-Qawa'id al-Kulliyyah, dalam Al-Sayyid 'Alawi b. Ahmad al-Saqqaf, Majmu'ah Sab'ah Kutub Mufidah, Mesir : Sharikah Maktabah Wa Matba'ah Mustafa al-Babi al-Halabi Wa Awladihi

Al-Shafi'i, M. (1413H/1993), al-Umm, Jil. 1. Beirut: Dar al-Kutub al-'Ilmiyyah

Al-Shaqafah, K. (2004), al-Dirasat al-Fiqhiyyah 'Ala Madhhab al-Imam al-Shafi'i Fi al-'Ibadat Wa Adillahtiha, Kaherah: Dar al-Salam

Al-Shatiri, A. (2009), Hashiah al-Sayyid al-'Allamah Ahmad ibn 'Umar al-Shatiri 'Ala Bughyah alMustarshidin Fi Talkhis Fatawa Ba' al-A'immah Min al-'Ulama' al-Muta'akhkhirin, jld.1, Abu Dhabi : Dar al-Faqih

Al-Shatiri, M. (1997), Sharh al-Yaqut al-Nafis, Damsyik: Dar al-Hawi

Al-Zuhayli, M. (1992), Marji' al-'Ulum al-Islamiyyah, Damsyik : Dar al-Ma'rifah

Ba'Alawi, S. (1994), Bughyah al-Mustarshidin Fi Talkhis Fatawa Ba' al-A'immah Min al-'Ulama' alMuta'akhkhirin, Beirut : Dar al-Fikr

BaFadl, Fadl bin 'Abd al-Rahman (t.th), al-Masail al-Muharrarah Wa al-Fawaid al-Muhabbarah, UAE : Dar al-Faqih Li al-Nasr Wa al-Tawzi'

BaSudan, M. (2018), al-Maqasid al-Saniyyah Ila al-Mawarid al-Haniyyah Fi Jam' al-Fawaid alFiqhiyyah, Amman : Dar al-Fath Li al-Dirasat al-Islamiyyah

Ag.Basir, D.H. (2014). Isu Batal Wuduk Semasa Tawaf : Analisa Pendekatan Tabung Haji. Jurnal Pusat Penataran Ilmu \& Bahasa, Bil. 20, 127-144

Ibnal-Jamal, 'A. (1434H), Fath al-Majid Fi Ahkam al-Taqlid, al-Dammam : Dar Ibn al-Jawzi

Al-'Abbadi, A. (1996), Hashiah al-'Allamah al-Shaykh Ahmad ibn al-Qasim al-'Abbadi. DIm. Ibn Hajar al-Haytami, Ahmad, Tuhfah al-Muhtaj Bi Sharh al-Minhaj, Beirut : Dar al-Kutub al-'Ilmiyyah 
Ibnal-Salah, U. (2011), Silah al-Nasik Fi Sifah al-Manasik, Tahqiq: Dr. 'Abd al-Karim ibn Sunaytan alUmary, Madinah: Universiti Islam Madinah

IbnHafid, M. (2013), Fatawa al-Faqih al-Shahid Ibn Hafid, Amman: Dar al-Maqasid

al-Haytami, I.H. (1996), Tuhfah al-Muhtaj Bi Sharh al-Minhaj, Beirut : Dar al-Kutub al-'Ilmiyyah

Laporan Jawatankuasa Penasihat Ibadat Haji. 1992. Muzakarah Haji Peringkat Kebangsaan kali kelapan.

Khairuldin, W.M.K.F.W., Embong, A.H., Anas, W.N.I.W.N., Mohd, H. \& Ismail, D. (2018), The Application of Technology in the Dissemination of Fatwas: A Study on Religious Institutions in Malaysia, International Journal of Civil Engineering and Technology, 9(7), 2018, pp. 15901596.

Khairuldin, W.M.K.F.W., Ismail, D., Anas, W.N.I.W.N., Ibrahim, I., \& Fauzi, N. (2016). Freedom of Speeches by Mufti According to Islam: Implication to Fatwa in Malaysia. International Journal of Academic Research in Business and Social Sciences. 6 (12). Pp 141-151.

Khairuldin, W.M. K. F. W. (2018). Fatwa Role in Education and Legal Dispute in Malaysia. International Journal of Academic Research in Progressive Education and Development, 7(4), 295-302.

Khairuldin, W. M. K. F. W., Embong, A. H., Anas, W. N. I. W. N., Ismail, D., \& Mokhtar, W. K. A.W. (2019). An Augmented Reality (AR) Approach in Educational Integration of Du'a in Islam. International Journal of Academic Research in Progressive Education and Development, 8(1), 32-39.

Khairuldin, W. M. K. F. W., Embong, A. H., \& Anas, W. N. I. W. N. (2019). Technological Approach in Education of Musafir (Muslim Traveler) in Islam: The Study on Mobile App Mysafar. International Journal of Academic Research in Progressive Education and Development, 8(1), 40-47.

Hanafi, L.H., Ahmad, A. \& Mohd, K.W. (2011). Rukhsah Dan Kesahihan Wuduk Jemaah Haji Malaysia Dalam Pemilihan Qaul Dalam Mazhab Syafie Di Tanah Suci Makkah. Jurnal Diskusi Syariah Dan Undang-Undang, Siri 5

Putera, M.S.S. (2018). Pembimbing Ibadah Haji Tabung Haji, Shah Alam. Temubual pada 22 November 2018.

Noor. S.A.M. (1996). Mengambil Wuduk Mengikut Mazhab Hanbali. Kertas Kerja Laporan Muzakarah Haji Peringkat Kebangsaan Kali Kedua Belas. Dewan Utama Kompleks Kelana Jaya, Selangor, 23-24 September. 